\title{
Venereal disease among immigrant workers in Vienna
}

\author{
MARGARETE LITTOMERICZKY AND ANTON LUGER \\ From the Department of VD Control, Public Health Centre, and the Ludwig Boltzmann Institut für \\ dermato-venerologische Serodiagnostik, Vienna
}

\section{Summary}

Official physical examinations of migrant workers upon immigration are required before work permits are issued. The screening of 74,983 applicants during 1972 to 1974 revealed sera reactive to serological tests for syphilis in $\mathbf{0 . 8}$ per cent. (range 0.5 to 1.1 per cent.) of all persons concerned and fifteen cases of early syphilis. The incidence of recent infections among immigrants is lower than that reported among the inhabitants of Vienna.

General statistics on the spread of venereal diseases among immigrant workers are not available after they start work. Some evidence is provided by those who had to be traced for compulsory examination because they had defaulted from treatment or follow-up, because they were suspected of clandestine prostitution, or because they were reported to be sources of infection.

257 ( 60.6 per cent.) of 414 individuals who were wanted for reasons of syphilis control could be located and eighteen ( 7 per cent.) of those who were examined had early infectious lesions.

Presented at the 28th General Assembly of the IUVDT, Malta, April, 1975

Head of the Department of VD Control, Public Health Centre, of Vienna, Gonzagagasse 23, A-1013, Vienna, Austria

Address for reprints: Prof. A. Luger, Department of Skin and Venereal Diseases, Hospital Vienna City-Lainz, Wolkersbergenstrasse 1, A-1130, Vienna, Austria
419 migrant workers were sought for gonorrhoea control; 276 (65.9 per cent.) were found and examination disclosed that 34 (12.3 per cent.) had symptoms of the disease.

Most cases of venereal disease were discovered among persons suspected of clandestine prostitution (38.5 per cent.) or who were reported as sources of infection (45.1 per cent.). The tracing of wanted persons showed approximately the same results in migrant workers as in Viennese citizens who were called for compulsory examination.

An evaluation of statements regarding sources of infection showed that 88.6 per cent. had contracted the disease from other foreign persons; this suggests that migrant workers live in a segregated ghetto situation. Women become integrated into the local population more quickly and easily than men.

\section{Introduction}

The general economic development in the past 15 years has led to the employment of large numbers of foreign workers in Vienna. This trend reached its peak in 1973 and has since declined (Table I). The percentage of foreign persons among all employees in Vienna was 5.9 per cent. in 1973 and 5.3 per cent. in 1974.

TABLE I Incidence of seroreactivity and of early syphilis among immigrants who applied for work in Vienna (1972-1974)

\begin{tabular}{|c|c|c|c|c|c|c|c|}
\hline \multirow[b]{2}{*}{ Year } & \multirow{2}{*}{$\begin{array}{l}\text { No. of } \\
\text { applicants }\end{array}$} & \multicolumn{2}{|c|}{ Reactive sera } & \multicolumn{2}{|c|}{ Cases of early syphilis } & \multirow{2}{*}{$\begin{array}{l}\text { No. of persons } \\
\text { with early } \\
\text { syphilis per } \\
100,000 \\
\text { applicants }\end{array}$} & \multirow{2}{*}{$\begin{array}{l}\text { No. of reported } \\
\text { cases of syphilis } \\
\text { per } 100,000 \\
\text { inhabitants of } \\
\text { Vienna }\end{array}$} \\
\hline & & No. & Per cent. & No. & Per cent. & & \\
\hline 1972 & 29,518 & 157 & 0.53 & 6 & 0.02 & $20 \cdot 3$ & $33 \cdot 1$ \\
\hline 1973 & 31,329 & 340 & 1.09 & 8 & 0.03 & $25 \cdot 5$ & $59 \cdot 3$ \\
\hline
\end{tabular}




\section{(1) Country of origin}

The majority of migrant workers, approximately $80^{\circ}$ per cent., came from Jugoslavia, about 12 per cent. from Turkey, and the rest from Italy, Tunisia, and Spain. These percentages have scarcely changed as the years have passed.

\section{(2) Legal" procedures at immigration}

The increase in the number of immigrants necessitated the introduction of special public health measures. All persons domiciled outside Austria who apply for work in Vienna have to pass a physical examination at a special clinic of the governmental public health control centre. The general intention is to avoid the introduction of communicable diseases such as tuberculosis, Salmonella infections, parasitoses, etc. All applicants also have a serological test for syphilis.

Those whose serum is reactive are then called for a thorough clinical examination at the Venereal Disease Control clinic and if necessary they are given adequate treatment. Finally they are given a health certificate which allows them to work and permits them to stay in the country for the duration of employment.

\section{(3) Results of examination of would-be immigrants}

(a) Serological tests Data are available on serological and clinical investigations since 1972. Table I shows the number of applicants who were tested each year, the number who were found to be reactive, and the percentage of reactors among the immigrants.

The reactivity rate in 1972 differed markedly from the rates in 1973 and 1974. There was a rise from 0.53 per cent. (1972) to 1.09 per cent. (1973) and to 0.95 per cent. (1974) because of a change in the test programme. Originally the Venereal Disease Reference Laboratory (VDRL) slide test was applied for screening. This procedure was changed on October 20,1972, and thereafter samples were tested qualitatively and quantitatively by the Automated Micro-Haemagglutination Assay with Treponema pallidum Antigen (AMHA-TP) (Gehmacher, 1973) as well as by the VDRL test. Reactive samples are now, and were in the past, regularly checked by the FTA-ABS test.

This change in screening method has naturally influenced the results. The incidence of reactivity per assay has not fluctuated during the period of observation, but there is a remarkable difference between the results of the two methods. The VDRL test detects only half or three-quarters of the actual number of reactors. This observation agrees with previous reports (Luger and Spendlingwimmer, 1974; Young, Henrichsen, and Robertson, 1974).

(b) Country of origin and reactivity No significant relationship could be observed between the incidence of seroreactivity and the nationality of the subjects, although reactive samples occurred somewhat more frequently in applicants from Jugoslavia. This difference amounted to only about 10 per cent.

(c) Incidence of early syphilis The observation that more samples were reactive in the AMHA-TP and in the FTA-ABS than in the VDRL already suggests that the infection had been acquired some time before. The results of the quantitative evaluation of the reactive sera in the VDRL test further confirmed this assumption. High titres were found in only a few samples.

Clinical examination of those with reactive sera revealed fifteen cases of early syphilis (Table I). There was no relationship between the number of those with reactive sera and the incidence of early syphilis.

The fifteen patients with recent infections may not have imported the disease but may have contracted it in Austria. Several migrant workers had tourist visas, valid for only 3 months, when they crossed the border. Some started work without legal contracts and came to obtain official work permits shortly before their visas expired. Therefore, the possibility of acquiring an infection since arriving in Austria cannot be excluded. The annual numbers of patients with early syphilis per 100,000 immigrants are much lower than the numbers of cases of syphilis in the entire population of Vienna (Table I, last two columns).

(d) Conclusions The result of the physical examination on entering the country indicates that migrant workers rarely have infectious syphilis.

\section{(4) Venereal infections after immigration}

There are no general statistics available on the incidence of venereal infections acquired by migrant workers after immigration. Legal contracts provide social insurance for all employees in Austria, and the migrant workers are not exempted from this law, so that foreigners receive medical care from practising physicians or at dispensaries. Venereal infections are treated through the same facilities.

Public health legislation requires the reporting of venereal infections by numbers only and guarantees anonymity to patients with regard to treatment and post-therapy control. However, language difficulties, misunderstandings, or ignorance of Austrian laws may cause migrant workers to interrupt treatment or default from subsequent control examinations. Such persons are reported to the health authorities by name and address. They are then sought out and brought to the VD Control clinic for compulsory examination and treatment. The tracing is performed by Public Health Authorities, or, in case of resistance, 
by the police. The same procedure is applied to persons who are reported to be sources of infection or contacts of infectious patients, who avoid the obligatory examination, or who are suspected of clandestine prostitution.

Table II shows the results of syphilis control among migrant workers. 414 persons were reported to the Public Health Authorities for having neglected the instructions of their physicians or for having transmitted the disease to others. Of these 414 individuals, 257 (62.1 per cent.) were located and brought in for examination. Eighteen had symptoms of early syphilis, and they all belonged to the group of those who were suspected of having caught the infection. Further details may be seen in Table II.

TABLE II Compulsory examinations for syphilis, 1972-1974

\begin{tabular}{|c|c|c|c|c|c|}
\hline \multirow{2}{*}{$\begin{array}{l}\text { Reason for } \\
\text { compulsory } \\
\text { examination }\end{array}$} & \multirow{2}{*}{$\begin{array}{l}\text { No. of } \\
\text { persons } \\
\text { sought }\end{array}$} & \multicolumn{2}{|c|}{ Persons examined } & \multicolumn{2}{|c|}{$\begin{array}{l}\text { Cases of recent } \\
\text { infection }\end{array}$} \\
\hline & & No. & Per cent. & No. & Per cent. \\
\hline $\begin{array}{l}\text { Interruption } \\
\text { of } \\
\text { treatment }\end{array}$ & 46 & 24 & $52 \cdot 2$ & & \\
\hline $\begin{array}{l}\text { Interruption } \\
\text { of follow-up }\end{array}$ & 310 & 186 & $60 \cdot 0$ & & \\
\hline $\begin{array}{l}\text { Suspected } \\
\text { of } \\
\text { prostitution }\end{array}$ & 42 & 34 & $81 \cdot 0$ & 14 & $41 \cdot 2$ \\
\hline $\begin{array}{l}\text { Source of } \\
\text { infection }\end{array}$ & 16 & 13 & $81 \cdot 3$ & 4 & $30 \cdot 8$ \\
\hline Total & 414 & 257 & $62 \cdot 1$ & 18 & $7 \cdot 0$ \\
\hline
\end{tabular}

Table III shows the experience in the control of gonorrhoea. The results are very similar to those in Table II.

TABLE III Compulsory examinations for gonorrhoea, 1972-1974

\begin{tabular}{|c|c|c|c|c|c|}
\hline \multirow{2}{*}{$\begin{array}{l}\text { Reason for } \\
\text { compulsory } \\
\text { examination }\end{array}$} & \multirow{2}{*}{$\begin{array}{l}\text { No. of } \\
\text { persons } \\
\text { sought }\end{array}$} & \multicolumn{2}{|c|}{ Persons examined } & \multicolumn{2}{|c|}{ Symptoms of disease } \\
\hline & & No. & Per cent. & No. & Per cent. \\
\hline $\begin{array}{l}\text { Interruption } \\
\text { of } \\
\text { treatment }\end{array}$ & 28 & 17 & $60 \cdot 7$ & 3 & $17 \cdot 6$ \\
\hline $\begin{array}{l}\text { Interruption } \\
\text { of follow-up }\end{array}$ & 315 & 203 & $64 \cdot 4$ & 6 & $3 \cdot 0$ \\
\hline $\begin{array}{l}\text { Suspected } \\
\text { of } \\
\text { prostitution }\end{array}$ & 22 & 18 & $81 \cdot 8$ & 6 & $33 \cdot 3$ \\
\hline $\begin{array}{l}\text { Source of } \\
\text { infection }\end{array}$ & 54 & 38 & $70 \cdot 4$ & 19 & $50 \cdot 0$ \\
\hline Total & 419 & 276 & $65 \cdot 9$ & 34 & $12 \cdot 3$ \\
\hline
\end{tabular}

(a) Results of Public Health work The summary of public health measures in VD control among foreign employees is presented in Table IV. Efforts to locate sources of infection and to trace persons who were suspected of clandestine prostitution were relatively successful, but the latter were frequently caught by the police and subsequently transferred to the VD Control clinic for examination. The tracing of persons who defaulted from treatment or who did not return for follow-up was more difficult, because often some time had elapsed before the treating physician reported such persons to the authorities and they had changed their quarters as well as their employment. The time element is most probably the reason why the physical examination disclosed fewer cases with symptoms of recent infection among defaulters than among those suspected of prostitution or of being sources of infection.

TABLE IV Compulsory examinations for syphilis and gonorrhoea, 1972-1974

\begin{tabular}{|c|c|c|c|c|c|}
\hline \multirow{2}{*}{$\begin{array}{l}\text { Reason for } \\
\text { compulsory } \\
\text { examination }\end{array}$} & \multirow{2}{*}{$\begin{array}{l}\text { No. of } \\
\text { persons } \\
\text { sought }\end{array}$} & \multicolumn{2}{|c|}{ Persons examined } & \multicolumn{2}{|c|}{ Symptoms of VD } \\
\hline & & No. & Per cent. & No. & Per cent. \\
\hline $\begin{array}{l}\text { Interruption } \\
\text { of } \\
\text { treatment }\end{array}$ & 74 & 41 & $55 \cdot 4$ & 3 & $7 \cdot 3$ \\
\hline $\begin{array}{l}\text { Interruption } \\
\text { of follow-up }\end{array}$ & 625 & 389 & $62 \cdot 2$ & 6 & 1.5 \\
\hline $\begin{array}{l}\text { Suspected } \\
\text { of } \\
\text { prostitution }\end{array}$ & 64 & 52 & $81 \cdot 3$ & 20 & $38 \cdot 5$ \\
\hline $\begin{array}{l}\text { Source of } \\
\text { infection }\end{array}$ & 70 & 51 & $72 \cdot 9$ & 23 & $45 \cdot 1$ \\
\hline Total & 833 & 533 & $64 \cdot 0$ & 52 & $9 \cdot 8$ \\
\hline
\end{tabular}

(b) Effectiveness of official control measures Table V compares the results of tracing sources of infection among migrant workers and among the local population of Vienna. The percentage of persons who could be located and brought in for compulsory examination is almost identical. The incidence of recent infections is in this respect higher among migrant workers than in the local population. This may be because the latter attend for medical treatment before they are found by the Public Health Authorities.

TABLE V Sources of infection, 1972-1974. Comparison of immigrant workers with population of Vienna

\begin{tabular}{|c|c|c|c|c|c|}
\hline \multirow{2}{*}{$\begin{array}{l}\text { Type of } \\
\text { people }\end{array}$} & \multirow{2}{*}{$\begin{array}{l}\text { No. of } \\
\text { persons } \\
\text { sought }\end{array}$} & \multicolumn{2}{|c|}{ Persons examined } & \multicolumn{2}{|c|}{ Recent infection } \\
\hline & & No. & Per cent. & No. & Per cent. \\
\hline $\begin{array}{l}\text { Immigrant } \\
\text { workers }\end{array}$ & 70 & 51 & $72 \cdot 9$ & 23 & $45 \cdot 1$ \\
\hline $\begin{array}{l}\text { Population } \\
\text { of Vienna }\end{array}$ & 843 & 630 & $74 \cdot 7$ & 215 & $34 \cdot 1$ \\
\hline
\end{tabular}


(c) Sources of infection Difficulties of communication, shame, fear of the consequences for themselves or for their contacts, and probably ignorance were the main obstacles to obtaining precise information on the sources of infection and on contacts. Infected foreign workers usually stated: 'I don't know' or 'I don't understand'. In rare instances they tried to cover the situation by saying: 'I don't know the name and the exact whereabouts of the person but I know enough to find her (or him) and I will settle the problem myself'. It is difficult in such cases to convince the patient that this is a wrong approach which may lead to another conflict with the law. Interpreters were rarely of much help to the interviewing physician or to the inquiring public health official, even if the language assistance came from nurses who had graduated in the patient's country. The usual statement of the interpreters is: 'You are dealing with a very primitive person'. It was,

TABLE VI Sources of infection, 1972-1975

\begin{tabular}{|c|c|c|c|c|c|}
\hline \multirow{3}{*}{ Diagnosis } & \multirow{3}{*}{$\begin{array}{l}\text { No. of } \\
\text { sources of } \\
\text { infection } \\
\text { reported }\end{array}$} & \multicolumn{4}{|c|}{ Disease contracted from } \\
\hline & & \multicolumn{2}{|c|}{ Foreigners } & \multicolumn{2}{|c|}{ Local inhabitants } \\
\hline & & No. & $\begin{array}{l}\text { Percent- } \\
\text { age of } \\
\text { persons } \\
\text { reported }\end{array}$ & No. & $\begin{array}{l}\text { Percent } \\
\text { age of } \\
\text { persons } \\
\text { reported }\end{array}$ \\
\hline Syphilis & 4 & 4 & & & \\
\hline Gonorrhoea & 82 & 72 & $87 \cdot 8$ & 10 & $12 \cdot 2$ \\
\hline Total & 86 & 76 & $88 \cdot 4$ & 10 & $11 \cdot 6$ \\
\hline
\end{tabular}

therefore, possible to gather information on only 86 sources of infection. Of these, $76(88.4$ per cent.) were foreigners and 10 (11.6 per cent.) belonged to the local population (Table VI). This suggests that immigrant workers live in a segregated or ghetto situation even in their intimate relations.

It is difficult for them to establish sexual contact with the indigenous population before they become acquainted with local customs. Even prostitutes resent migrant workers as customers because they are not certain of their sexual behaviour and because their finances are usually limited; most of these immigrants try to save money rather than to spend it.

Female immigrants make contact with the local population more easily and integrate more quickly with the inhabitants of the host country.

(d) Conclusions There is no information available which would indicate an increased incidence of venereal diseases among migrant workers after immigration. Sexual relations with the local population appear to be very limited.

\section{References}

GEHMACHER, E. (1973) 'Gastarbeiterwirtschaftliche und sociale Herausforderung'. Europa-verlag, Vienna

Luger, A., and Spendlingwimmer, I. (1974) Hautarzt, 25, 238

Young, H., Henrichsen, C., and Robertson, D. H. H. (1974) 'The Treponema Pallidum haemagglutination test as a screening procedure for the diagnosis of syphilis'. WHO/VDT/RES. 74.313 